\title{
Pelatihan Komputer untuk Meningkatkan Ketrampilan dan Motivasi Belajar Anak-Anak Yatim di Rumah Yatim Bekasi
}

\author{
Adi Wibowo Noor Fikri ${ }^{1}$, Bintang Narpati ${ }^{1, *}$, Eri Bukhari ${ }^{1}$, M Fadhli Nursal ${ }^{1}$ \\ ${ }^{1}$ Fakultas Ekonomi dan Bisnis; Universitas Bhayangkara Jakarta Raya; Jl. Raya Perjuangan \\ No.1 Marga Mulya Bekasi 17121, telp/fax 021-88955882/ 021-8895883; e-mail: \\ adi.noor@dsn.ubharajaya.ac.id, bintang.narpati@dsn.ubharajaya.ac.id, \\ eri.bukhari@dsn.ubharajaya.ac.id, fadhli.nursal@dsn.ubharajaya.ac.id \\ * Korespondensi: e-mail: bintang.narpati@dsn.ubharajaya.ac.id
}

Submitted: 03/06/2021; Revised: 10/06/2021; Accepted: 16/06/2021; Published: 28/06/2021

\begin{abstract}
The purpose of this Community Service Activity (PKM) is to provide introduction and computer training to orphans at the Bekasi Orphanage. Participants in this training are orphans from Junior High School (SMP) to Senior High School (SMA) level. This Community Service Activity (PKM) is a continuation of the previous PKM activities, namely the first is Simple Bookkeeping Training and Socialization on Introduction to Savings, and the next is Handicraft Training which is held at Rumah Yatim Bekasi. The method used in this training is theory and practice which is guided by a team of lecturers from the Faculty of Economics, University of Bhayangkara Jakarta Raya, and learners are given a module book as guide material in computer training. Through this activity, students can find out and understand about computers, especially Microsoft Office, to help with school work and other tasks in daily activities. The result of this training is that students understand the role of computers and the use of Microsoft Office and are motivated to complete tasks using computers.
\end{abstract}

Keywords: Computer Training, Skills and Learning Motivation.

\begin{abstract}
Abstrak
Tujuan dari Kegiatan Pengabdian Masyarakat (PKM) ini adalah untuk memberikan pengenalan dan pelatihan komputer kepada anak - anak yatim di Rumah Yatim Bekasi. Peserta pelatihan ini adalah anak - anak yatim dari Sekolah Menengah Pertama (SMP) sampai dengan tingkat Sekolah Menengah Atas (SMA). Kegiatan Pengabdian Kepada Masyarakat (PKM) ini merupakan kelanjutan dari kegiatan PKM sebelumnya yaitu yang pertama adalah Pelatihan Pembukuan Sederhana dan Sosialisasi Pengenalan Tabungan dan yang berikutnya adalah Pelatihan Kerajinan Tangan yang diselenggarakan di Rumah Yatim Bekasi. Metode yang digunakan dalam pelatihan ini adalah teori dan praktek yang dipandu oleh tim dosen dari Fakultas Ekonomi Universitas Bhayangkara Jakarta Raya dan pada pelatihan ini para peserta didik diberikan buku modul sebagai bahan panduan dalam pelatihan komputer. Melalui kegiatan ini, peserta didik dapat mengetahui dan memahami mengenai komputer khususnya Microsoft Office untuk membantu tugas sekolah maupun tugas lainnya dalam aktivitas sehari-hari. Hasil dari pelatihan ini adalah peserta didik lebih memahami peran dari komputer dan penggunaan Microsoft Office dan termotivasi untuk menyelesaikan tugas menggunakan komputer.
\end{abstract}

Kata kunci: Pelatihan Komputer, Ketrampilan dan Motivasi Belajar 


\section{Pendahuluan}

Internet of Thing (loT) merupakan sarana yang sangat dibutuhkan di era Revolusi Industri 4.0 ini. Hampir sebagian kegiatan atau transaksi yang dilakukan sehari - hari memerlukan yang namanya internet. Penggunaan internet sudah banyak dilakukan oleh rata - rata dari remaja sampai orang tua bahkan anak - anak usia belum sekolahpun sudah mengenal adanya internet tanpa secara sadar yang mereka gunakan dalam bermain misalnya dalam bentuk handphone, gadget dan sebagainya. Untuk membantu pengenalan komputer, beberapa perusahaan komputer membuat perancangan berupa game edukasi sebagai pengenalan terhadap anak usia dini berupa pengenalan angka dan huruf. Membuat analisa dan perancangan game edukatif perihal angka dan huruf adalah hal mendasar untuk untuk anak usia dini (Fithri \& Setiawan, 2017). Perkembangan internet dipergunakan oleh kalangan pebisnis, institusi pendidikan seperti untuk penyampaian informasi, dan berbagi dokumen antar bagian (Fryonanda \& Ahmad, 2017). Komputer sendiri memiliki pengertian serangkaian alat elektronik yang mampu melakukan banyak tugas dan memiliki banyak fungsi (Aruna Sachi Kayana, 2014).

Sebelum Internet menjadi suatu kebutuhan "pokok" masa kini, dahulu internet hanya merupakan alat yang untuk menggantikan mesin tik yang sering digunakan untuk kebutuhan administrasi di kantor. Mesin tik saat itu sekitar akhir tahun 1980-an masih menjadi primadona untuk pengerjaan perkantoran. Mesin tik manual yang menggunakan pita karbon dengan dilengkapi tombol-tombol huruf, angka dan simbol tersebut mampu membuat pekerjaan dikantor berjalan. Kelebihan mesin tik saat itu adalah pencetakan langsung pada kertas yang diketik dan tidak membutuhkan alat tambahan seperti printer ataupun alat sejenis lainnya untuk pencetakan. Hanya dengan memasukan kertas dan menambahkan karbon dibelakang kertas bila ingin membuat copy dari pengetikan yang dibuat.

Dengan adanya internet tersebut, sudah semestinya generasi sekarang sudah mampu mengaplikasikan internet. Dalam penggunaan internet tidak jarang kita temui aplikasi-aplikasi untuk memberikan kemudahan bagi penggunanya dalam melakukan tugas sehari-hari. Sebagai contoh kita sering lihat dalam tampilan di televisi ataupun media sosial lainnya seperti youtube mengenai penggunaan Microsoft office dalam membantu pekerjaan kita sehari-hari. Peran dari komputer itu sendiri banyak sekali membantu dalam pekerjaan baik dari anak-anak khususnya yang masih dalam belajar (sekolah) sampai orang tua. Pengenalan komputer sejak dini membantu pengembangan analisa dan daya pikir bagi para penggunanya.

Selain itu aplikasi komputer seperti MS Office dalam hal ini MS Word, Excel dan Power Point sudah umum dan sering digunakan dalam membantu tugas dan pekerjaan yang dikerjakan. Menghemat, waktu, tenaga, biaya dan meminimalisir kesalahan-kesalahan dalam pengetikan administrasi ataupun dalam melakukan presentasi. Sebagai contoh MS Word yang dapat melakukan dengan pengeditan dan variasi dalam penulisan. Begitupula dengan MS Excel, dengan aplikasi ini sangat memudahkan penggunanya dalam pekerjaan yang bersifat khususnya menghitung. Selain dilengkapi dengan gambar-gambar grafik ataupun media lainnya, aplikasi ini juga mampu membantu memecahkan masalah statistic yang dikerjakan oleh para penggunanya. 
MS Power point dapat memberikan solusi dalam melakukan presentasi agar audience memahami komunikasi yang dilakukan oleh presenter.

Pembelajaran Microsoft office seperti MS Word, Excel dan Power Point dapat membantu khususnya anak - anak yatim dalam mengerjakan pekerjaan sekolah dan dapat mengembangkan ketrampilan melalui aplikasi - aplikasi tersebut untuk menghasilkan keuntungan, selain itu dengan adanya kemudahan dari aplikasi komputer terebut, dapat meningkatkan motivasi belajar terhadap anak - anak yatim kepada pelajaran di sekolah karena sangat membantu dalam menyelesaikan tugas sekolah. Namun Microsoft Exce/masih terlalu sulit untuk di pahami penggunaanya bagi siswa karena adanya tampilan dan fungsi pemakaiannya banyak menggunakan rumus berupa logika perhitungan (Kusbianto, 2013). Pelatihan komputer saat ini merupakan kebutuhan bagi setiap orang, karena hampir semua aktivitas pekerjaan menggunakan komputer.

Pembentukan jiwa kewirausahaan sudah diberikan kepada anak - anak yatim kota Bekasi melalui kegiatan pengabdian kepada masyarakat sebelumnya. Melalui pelatihan komputer ini, diharapkan gap yang terjadi antara jiwa wirausaha dengan kegiatan sehari - hari dapat diaplikasikan lewat pelatihan ini. Aplikasi komputer tersebut dapat pula digunakan untuk menghasilkan uang bagi anak - anak yatim, sebagai contoh mereka dapat membuka jasa layanan pengetikan ataupun jasa layanan lainnya. Selain itu pendidikan nonformal seperti pelatihan komputer ini yang diberikan kepada anak-anak yatim kota Bekasi memiliki tujuan untuk melayani masyarakat atau warga supaya mampu untuk berkembang sejak dini dan meningkatkan harkat dan martabat yang berlangsung hingga masa depannya (Afrianti \& Bartin, 2020).

Pelatihan inipun dapat membantu pengurus asrama yatim Bekasi dalam hal pencatatan transaksi yang terjadi selama ini. Melalui kegiatan ini, anak - anak yatim diberdayakan untuk dapat memiliki jiwa mandiri dan memiliki jiwa wirausaha untuk dapat dikembangkan pada masa depan nanti. Pelaksanaan pelatihan ini dapat dikembangkan dengan lancar apabila tidak ditemukan adanya kendala-kendala seperti kurangnya tenaga ahli di bidang teknisi komputer, adanya keterbatasan dana dalam pelatihan, dan kurangnya motivasi pada peserta didik untuk mengikuti pelatihan (Hidayatulloh, 2019).

Pelatihan komputer untuk meningkatkan ketrampilan ini, pada tahap awal dapat dilakukan secara gratis dulu untuk meningkatkan minat dan motivasi belajar bagi peserta didik. Dengan diberikan pelatihan komputer secara gratis ini adalah untuk menumbuhkan kesadaran mengenai pentingnya teknologi dan menciptakan minta serta motivasi dalam melakukan perubahan. Disisi lain terdapat faktor penghambat dalam pelatihan ini seperti kurangnya sarana dan prasarana dalam pelaksanaan pelatihan komputer gratis ini dan masih adanya sikap yang tradisional terhadap pelatihan komputer ini (Dewi, 2016).

Pelatihan inipun dapat membantu pengurus asrama yatim Bekasi dalam hal pencatatan transaksi yang terjadi selama ini. Melalui kegiatan ini, anak - anak yatim diberdayakan untuk dapat memiliki jiwa mandiri dan memiliki jiwa wirausaha untuk dapat dikembangkan pada masa depan nanti. 
Tujuan kegiatan pelatihan komputer ini adalah a) Memberikan pengetahuan mengenai perangkat komputer. b) Memberikan pelatihan aplikasi komputer yaitu MS Word, Excel dan Power Point. c) Memberikan motivasi bagi anak - anak yatim untuk mengembangkan ide - ide kreatifnya melalui aplikasi komputer ini. yang dapat menghasilkan keuntungan. d) Membentuk karakter jiwa anak - anak yatim menjadi jiwa yang mandiri. e) Membentuk pemikiran dari peluang menjadi uang. f) Memberikan pengetahuan mengenai pencatatan transaksi harian yang dapat dilakukan pada komputer.

Pengabdian kepada masyarakat ini dalam memberikan pelatihan komputer kepada anak - anak yatim memberikan manfaat a) Anak - anak yatim dapat memahami arti pentingnya pelatihan komputer dalam kegiatan sehari - hari; b) Anak - anak yatim dapat mengaplikasikan program komputer untuk dapat menghasilkan keuntungan; c) Melalui pelatihan ini dapat menstimulus inovasi ide-ide kreatif anak-anak yatim sehingga dapat direalisasikan; d) Meningkatkan ketrampilan bagi diri sendiri dan bermanfaat bagi orang lain; e) Bagi institusi atau lembaga rumah yatim ini diharapkan pelatihan ini dapat membantu meringankan tugas sehari hari; f) Melalui pelatihan ini menunjukkan bahwa Universitas Bhayangkara Jakarta Raya peduli terhadap masyarakat sekitar dalam melaksanakan Tri Dharma Perguruan Tinggi sehingga dapat meningkatkan akreditasi dan lebih mendekatkan Universitas Bhayangkara Jakarta Raya kepada masyarakat sekitarnya.

\section{Metode Pelaksanaan}

Pelatihan ini terbagi dalam 4 (empat) bahasan yang diberikan oleh masing - masing dosen, yaitu a) Pengenalan mengenai perangkat komputer, manfaat dan kekuranganya, termasuk penggunaan jaringan internet yang cenderung meningkat digunakaan saat ini; b) Pelatihan Microsoft Word dengan materi yang sering digunakan dalam mengerjakan tugas; c) Pelatihan Microsoft Excel dengan materi dasar - dasar pembuatan tabel dan penghitungan; d) Pelatihan Microsoft Power Point dengan materi pembuatan presentasi.

Sebelum melakukan kegiatan ini, tim dosen dari Universitas Bhayangkara Jakarta Raya melakukan observasi dan wawancara dengan pengurus asrama, karyawan dan anak - anak yatim yang berada dalam asrama. Dalam observasi dan wawancara, pengurus dari Rumah Yatim Bekasi, meminta dari tim dosen Fakultas Ekonomi Universitas Bhayangkara Jakarta Raya untuk melakukan pelatihan komputer di Rumah Yatim Bekasi ini, karena menurut yang bersangkutan bahwa anak - anak yatim ini belum memahami penggunaan komputerisasi yang sering digunakan dalam mengerjakan tugas sekolah maupun tugas lainnya, seperti pengetikan, penghitungan maupun bahan untuk presentasi pada kegiatan sekolah ataupun lainnya.

Kegiatan ini meliputi 40 orang anak - anak yatim terdiri dari 25 dengan pendidikan SMA yaitu 10 laki-laki dan 15 wanita, sedangkan untuk pendidikan SMP terdiri dari 7 laki - laki dan 8 perempuan. Selain itu pelatihan juga diikuti oleh karyawan dan pengurus asrama. Metode yang digunakan adalah ceramah berupa teori dengan praktek serta tanya jawab mengenai materi materi yang diajarkan. Pelaksanaan ini dilakukan dengan edukasi yang mendidik agar para 
peserta didik tidak jenuh dalam memahami pelajaran komputer yaitu dengan diselingi pertanyaan-pertanyaan yang bersifat menyenangkan.
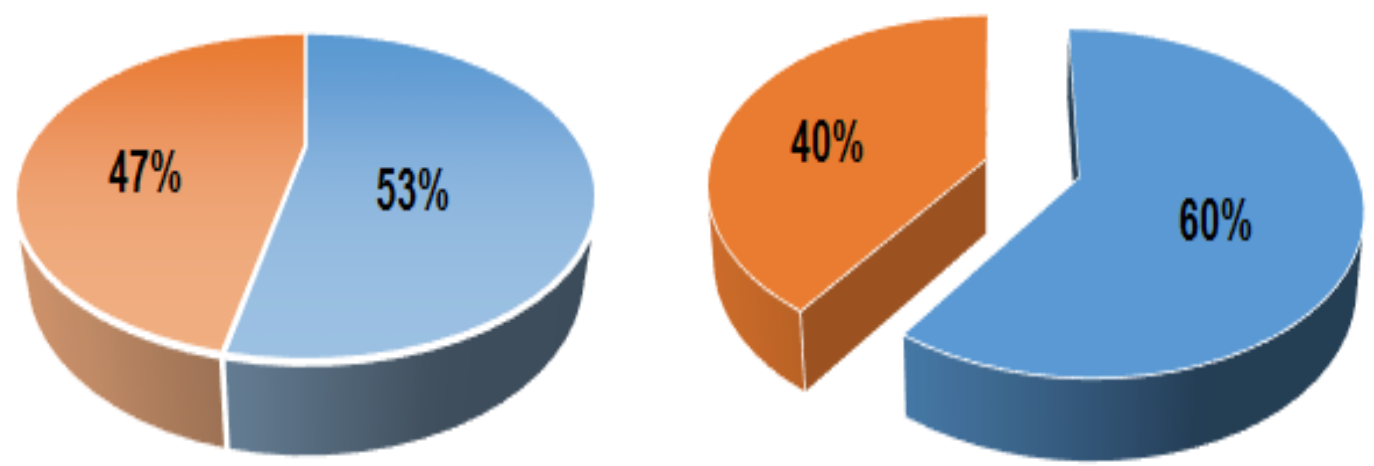

Sumber : Rumah Yatim Bekasi (2020)

\section{Gambar 1. Komposisi Peserta Didik}

Untuk mempermudah bagi peserta didik, tim dosen telah membagikan modul pelatihan komputer dengan materi pengenalan komputer, Microsoft Word, Microsoft Excel dan Microsoft Power Point. Materi dalam pelatihan ini dapat dilihat pada tabel 1.

Tabel 1. Materi Pelatihan Komputer

\begin{tabular}{|c|c|}
\hline Materi & Pokok Bahasan \\
\hline Pengenalan Komputer & $\begin{array}{l}\text { 1. Pengenalan perangkat komputer yang terdiri dari CPU, Monitor dan } \\
\text { Printer } \\
\text { 2. Menjelaskan mengenai fungsi dari masing - masing perangkat tersebut } \\
\text { 3. Menjelaskan pemakaian internet menggunakan jaringan untuk berbagai } \\
\text { aktivitas dalam kehidupan sehari - hari } \\
\text { 4. Menjelaskan pentingnya penggunaan internet dalam jaman digitalisasi }\end{array}$ \\
\hline Microsoft Word & $\begin{array}{l}\text { 1. Pengenalan dan penjelasan Microsoft Word berupa teori dengan } \\
\text { menggunakan buku modul } \\
\text { 2. Melakukan praktek dengan mengikuti instruksi dari nara sumber } \\
\text { 3. Memberikan latihan - latihan untuk memperkuat pengertian Microsoft } \\
\text { Word }\end{array}$ \\
\hline Microsoft Excel & $\begin{array}{l}\text { 1. Pengenalan dan penjelasan Microsoft Excel berupa teori dengan } \\
\text { menggunakan buku modul } \\
\text { 2. Melakukan praktek dengan mengikuti instruksi dari nara sumber } \\
\text { 3. Memberikan latihan - latihan untuk memperkuat pengertian Microsoft } \\
\text { Excel }\end{array}$ \\
\hline Microsoft Power Point & $\begin{array}{l}\text { 1. Pengenalan dan penjelasan Microsoft Power Point berupa teori dengan } \\
\text { menggunakan buku modul } \\
\text { 2. Melakukan praktek dengan mengikuti instruksi dari nara sumber } \\
\text { 3. Memberikan latihan - latihan untuk memperkuat pengertian Microsoft } \\
\text { Power Point } \\
\text { 4. Melakukan presentasi sesuai dengan materi yang telah dibuat oleh } \\
\text { masing - masing peserta didik }\end{array}$ \\
\hline
\end{tabular}

Sumber: Hasil Pelaksanaan (2021) 
Sebelum melakukan kegiatan ini, terlebih dahulu nara sumber dan seluruh peserta dapat dijelaskan, sebagai berikut a) Sebelum pelatihan komputer ini dilaksanakan, dilakukan pre-test dahulu kepada peserta didik untuk mengetahui sejauh mana pengetahuan mengenai komputer dan aplikasinya; b) Pelatihan komputer yang diberikan oleh masing-masing dosen dengan materi yang telah diatur dalam pengajaran. Pada pelatihan ini, teori hanya diberikan sekitar tiga puluh persen dan sisanya adalah praktek. Dalam praktek komputer ini, banyak sekali pertanyaanpertanyaan yang disampaikan oleh peserta didik yang terlihat semangat mengikuti praktikum ini. Walaupun pelatihan tidak dilakukan dalam periode bulanan namun ketrampilan dari peserta didik dalam menggunakan komputer sudah dapat dikatakan cepat memahami materi dan cepat dalam pengerjaannya; c) Setelah selesai praktek pelatihan komputer, dilakukan post-test untuk mengukur pemahaman komputer dan aplikasinya; d) Melalui pelatihan komputer ini, peserta didik dibuatkan modul untuk lebih memahami dan dapat dipelajari kembali materi yang telah diajarkan. Untuk meningkatkan ketrampilan para peserta didik, nara sumber meberikan tugas pekerjaan rumah yang ditargetkan satu bulan telah selesai dikerjakan setelah kegiatan, untuk dapat melihat adanya peningkatan dalam pembelajaran; e) Monitoring akan dilakukan setelah sebulan pertama untuk mengetahui adanya peningkatan dalam pemahaman penggunaan komputer dikalangan anak-anak yatim di Rumah Yatim kota Bekasi.
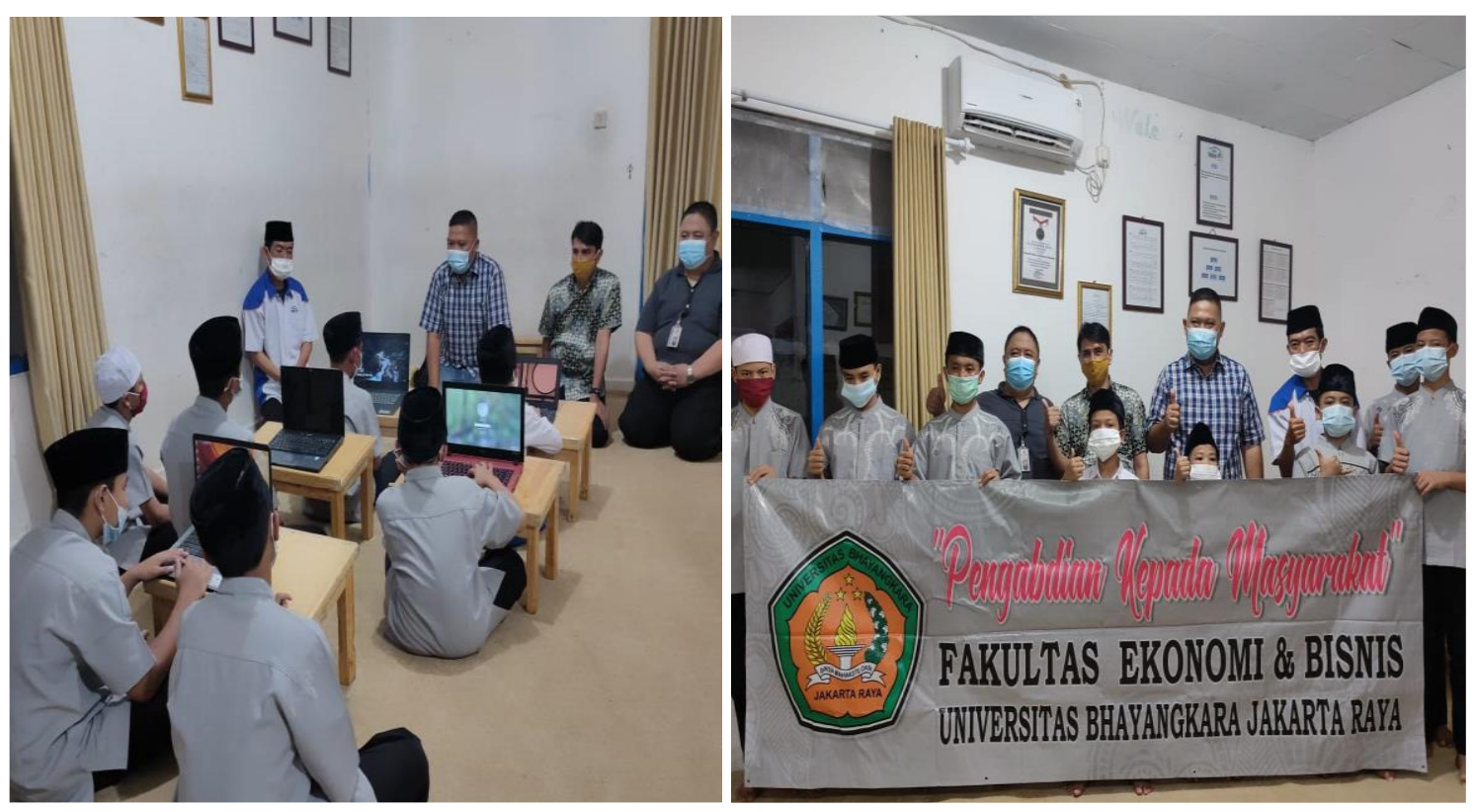

Sumber: Hasil Pelaksanaan (2021)

Gambar 2. Foto Kegiatan Pengabdian Masyarakat (PKM), 2020

\section{Hasil dan Pembahasan}

Hasil dari kegiatan Pengabdian Kepada Masyarakat (PKM) ini menunjukkan adanya beberapa peningkatan yaitu dengan adanya pre-test yang dilakukan kepada peserta didik Program Pengabdian Kepada Masyarakat (PKM) berupa pelatihan komputer merupakan lanjutan dari program Pengabdian Kepada Masyarakat (PKM) sebelumnya yang kerajinan tangan dengan bahan kertas dan plastik dan mengenalkan pembukuan sederhana dan sosialisasi tabungan ini 
mengikuti peserta yang ada sebelumnya bagi anak - anak yatim dengan lokasi yang sama yaitu di Rumah Yatim kota Bekasi. Peserta yang merupakan anak - anak yatim yang berusia 13 tahun ke atas, akan diberikan pelatihan dengan lokasi di Rumah Yatim di Bekasi.

Pada hakekatnya, kegiatan pelatihan komputer ini adalah salah satu cara untuk meningkatkan pengetahuan dan ketrampilan bagi anak - anak yatim yang berada dalam naungan Rumah Yatim Bekasi. Pasca pelatihan komputer ini diharapkan kepada anak - anak yatim (peserta didik) sebagai berikut: a) Peserta didik dapat merealisasikan ilmu pengetahuan tentang pelatihan komputer yang mereka dapatkan; b) Peserta didik dapat mengembangkan ide - ide kreatif selanjutnya melalui aplikasi komputer; c) Peserta didik dapat membantu transaksi yang ada di rumah yatim Bekasi baik itu pendataan donatur maupun transaksi keuangan yang poernah diajarkan pada kegiatan PKM sebelumnya; d) Peserta didik dapat melihat peluang yang dapat mendatangkan uang melalui pengembangan ketrampilan dengan komputer, sehingga dana yang didapat dapat dicatat sebagai laporan pemasukan dan yang akan ditabung di bank; e) Peserta didik dapat mengetahui dan memahami pemanfaatan jaringan komputer seperti proses pengiriman data secara cepat, berinteraksi dengan orang lain dari berbagai negara dengan mudah, dapat mengirim teks, gambar, audio, video dan dapat mengakses berita atau informasi (Nesabamedia.com, 2017); f) Hasil dari post-test yang telah dilaksanakan kepada 40 anak yatim di Rumah Yatim Bekasi, menunjukkan adanya peningkatan pengetahuan baik mengenai pengenalan perangkat komputer maupun aplikasi dari Microsoft Office.

Dengan adanya hasil akhir atau post-test yang dilakukan terhadap peserta didik (anakanak yatim) ini memberikan kesimpulan bahwa dengan diberikan test ini secara mandiri menunjukan adanya peningkatan kemampuan yang signifikan dalam mengoperasikan komputer yang telah diajarkan. Hal ini diperkuat dengan penelitian yang dilakukan oleh (Suratmi et al., 2014) melalui peningkatan ketrrampilan menggunakan komputer terhadap kelompok musyawarah guru mata pelajaran. Dari hasil pelatihan komputer ini diharapkan peserta didik memiliki kemampuan kognitif, afektif serta ketrampilan yang membantu peserta didik untuk mudah mendapatkan pekerjaan dan berwirausaha (Trisnawati et al., 2017). 


\section{Daftar Nilai}

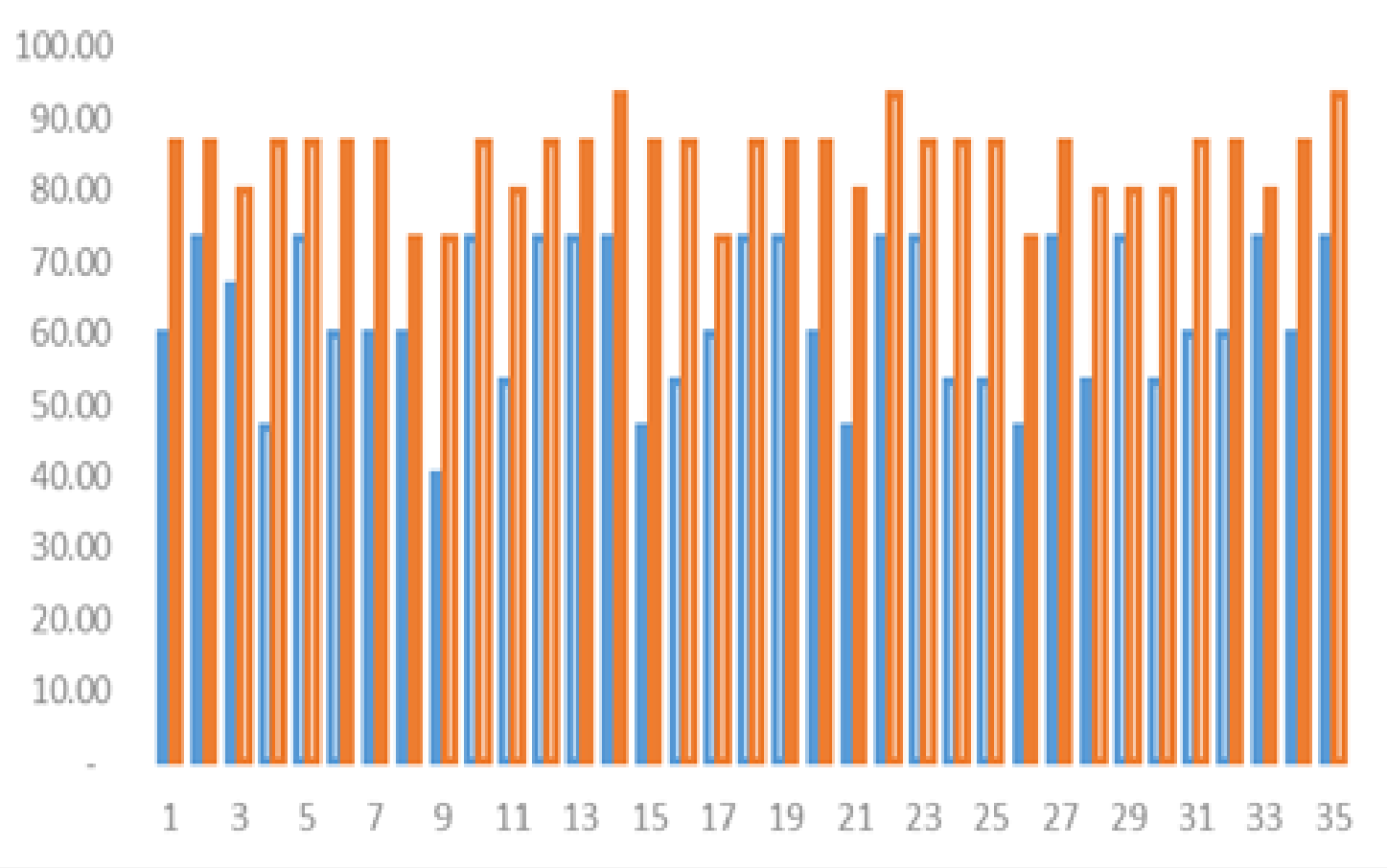

Sumber: Hasil Pelaksanaan (2021)

Grafik 3. Nilai Post-Test Pelatihan Komputer

\section{Kesimpulan}

Kesimpulan dari kegiatan Pengabdian Kepada Masyarakat (PKM) ini bagi anak - anak yatim adalah a) Memberikan pengetahuan mengenai perangkat komputer; b) Memberikan pelatihan aplikasi komputer yaitu MS Word, Excel dan Power Point; c) Memberikan motivasi bagi anak - anak yatim untuk mengembangkan ide - ide kreatifnya melalui aplikasi komputer ini. yang dapat menghasilkan keuntungan; d) Membentuk karakter jiwa anak - anak yatim menjadi jiwa yang mandiri; e) Membentuk pemikiran dari peluang menjadi uang; f) Memberikan pengetahuan mengenai pencatatan transaksi harian yang dapat dilakukan pada komputer. Selain itu beberapa manfaat yang didapat dari pelatihan ini adalah anak-anak yatim dapat memahami arti pentingnya pelatihan komputer dalam kegiatan sehari-hari dan dapat mengaplikasikan program komputer untuk dapat menghasilkan keuntungan. Melalui pelatihan ini dapat menstimulus inovasi ide-ide kreatif anak-anak yatim sehingga dapat direalisasikan. Pelatihan ini juga dapat meningkatkan ketrampilan bagi diri sendiri dan bermanfaat bagi orang lain. Bagi institusi atau lembaga rumah yatim ini diharapkan pelatihan ini dapat membantu meringankan tugas sehari-hari. Sebaiknya pelatihan komputer ini menjalin kemitraan dengan berbagai pihak seperti dinas pendidikan, dinas tenaga kerja, dan industri-industri yang berada di wilayah Bekasi untuk dapat menampung para lulusan pelatihan ini kedepannya. Seperti halnya penelitian yang telah dilakukan oleh (Ariyanti, 2017) di wilayah Majalaya. Melalui pelatihan ini menunjukkan bahwa Universitas Bhayangkara 
Jakarta Raya peduli terhadap masyarakat sekitar dalam melaksanakan Tri Dharma Perguruan Tinggi sehingga dapat meningkatkan akreditasi dan lebih mendekatkan Universitas Bhayangkara Jakarta Raya kepada masyarakat sekitarnya.

\section{Daftar Pustaka}

Afrianti, V., \& Bartin, T. (2020). Hubungan Antara Motivasi Belajar Dengan Aktivitas Belajar Peserta Pelatihan Bahasa Inggris di Lembaga Kursus dan Pelatihan Hazika Education Centre Padang. Ranah Research; Journal of Multidicsiplinary Research and Development, Vol.2 No.3(e-isssn: 2655-0865), 9. https://jurnal.ranahresearch.com/index.php/R2J/article/view/290/259

Ariyanti, E. H. (2017). Pengelolaan Pembelajaran Kursus Dalam Menumbuhkan Kemampuan Berwirausaha Lulusan Komputer Desain Grafis di LKP IKAM Majalaya. Jurnal Pendidikan Luar Sekolah, 13 No. 1. https://ejournal.upi.edu/index.php/pls/article/view/8721

Aruna Sachi Kayana. (2014). Pengertian Komputer, Definisi Komputer Menurut Para Ahli. Pengertian Komputer, Definisi Komputer Menurut Para Ahli.

Dewi, A. C. (2016). Pelatihan Komputer Gratis di Kampoeng Pintar Sebagai Pemberdayaan Masyarakat (Studi Kasus di Desa Suwawal Timur, Pakis Aji Kabupaten Jepara) [Universitas Negeri Semarang]. http://lib.unnes.ac.id/28481/1/1201412040.pdf

Fithri, D. L., \& Setiawan, D. A. (2017). Analisa Dan Perancangan Game Edukasi Sebagai Motivasi Belajar Untuk Anak Usia Dini. Simetris: Jurnal Teknik Mesin, Elektro Dan Ilmu Komputer. https://doi.org/10.24176/simet.v8i1.959

Fryonanda, H., \& Ahmad, T. (2017). Analisis Website Perguruan Tinggi Berdasarkan Keinginan Search Engine Menggunakan Automated Software Testing GTmetrix. Analisis Website Perguruan Tinggi Berdasarkan.

Hidayatulloh, H. N. (2019). Implementasi Program Pelatihan Komputer bagi Warga Belajar Paket

C di PKBM Bina Terampil Mandiri Kertawangi. Jurnal Comm-Edu, e-ISSN 2615-1480 pISSN 2622-5492. https://doi.org/10.22460/comm-edu.v2i1.2450

Kusbianto, F. (2013). Media Pembelajaran Microsoft Office Excel 2010 Untuk Sekolah Dasar Negeri 03 Macanan Fery Kusbianto. Seminar Riset Unggulan Nasional Informatika Dan Komputer FTI UNSA.

nesabamedia.com. (2017). Pengertian, Manfaat dan Macam-Macam Jaringan Komputer (Lengkap). In Http://Www.Nesabamedia.Com/Pengertian-Manfaat-Dan-Macam-MacamJaringan-Komputer/.

Suratmi, S., Muldiani, R. F., Purwaningsih, S. S., \& Sartika, E. (2014). Peningkatan Ketrampilan Penggunaan Komputer Dalam Pembelajaran Untuk Kelompok Musyawarah Guru Mata Pelajaran (MGMP) Matematika, IPA \& Fisika SMK Se Kecamatan Lembang Kabupaten Bandung Barat Jawa Barat. SIGMA-Mu (Jurnal Penelitian \& Gagasan Sains Dan Matematika Terapan). https://doi.org/https://doi.org/10.35313/sigmamu.v6i2.882 
Trisnawati, B., Sudadio, S., \& Fauzi, A. (2017). Peningkatan Life Skills Warga Belajar melalui Kursus Komputer di PKBM Cipta Cendekia Kota Tangerang. Journal of Nonformal Education and Community Empowerment, 1 (2)(p-ISSN 2549-1539 e-ISSN 2579-4256), 176-185. https://doi.org/https://doi.org/10.15294/pls.v1i2.19418 